\title{
Öğretmenlik Meslek Etiği Açısından Hediye Alma: Örnek Olay Ekseninde
}

\section{Değerlendirme*}

\section{Özge ERDEMLİ*** ， Tuğba GÜNER DEMİR***}

Öz: $\mathrm{Bu}$ çalışmanın amacı öğretmenlerin hediye alma davranışını haklı gösterirken ve ussallaştırırken kullandıkları yaklaşımları tespit etmektir. Bu amaçla öğretmenlerin görüşlerine başvurulmuştur. Çalışma öğretmenlerin hediye alma davranışını nasıl haklı göstermeye çalıştıklarını derinlemesine incelediğinden nitel araştırma yöntemlerinden durum çalışması benimsenerek yapılmıştır. Bu araştırmanın çalışma grubunu Ankara ilinde kamu ilkokul ve ortaokullarında görev yapan 15 öğretmen oluşturmaktadır. Çalışmada öğretmenlere hediye alma durumuyla ilgili bir örnek olay sunularak bu durumda ne yapacakları ve bu kararlarının gerekçeleri sorulmuş, buna göre bu kararlarını haklı gösterirken ve ussallaştırırken hangi yaklaşımları kullandıkları belirlenmeye çalışılmıştır. Toplanan veriler betimsel analiz tekniği kullanılarak analiz edilmiştir. Araştırma bulgularına göre öğretmenlerin çoğunun kendilerine verilen örnek olayda etik karar verdikleri, ancak bazı öğretmenlerin çeşitli gerekçelerle hediye almayı kabul edeceklerini belirtikleri tespit edilmiştir. Öğretmenlerin bu etik dışı kararlarını haklı gösterirken "Sahte gereklilikler tuzağı" ussallaştırma yaklaşımını kullandıkları görülmüştür.

Anahtar Kelimeler: Hediye, etik dışı davranış, öğretmen, meslek etiği, ussallaştırma.

\footnotetext{
* Bu çalışma Türkiye ve Orta Doğu Amme İdaresi Enstitü (TODAİE) tarafindan düzenlenen II. Kamu Etiği Kongresi'nde sunulan “Örnek Olaylar Ekseninde Öğretmenlerin Etik Dışı Davranışları Ussallaştırma Yaklaşımları” isimli sözlü bildirinin bir bölümünden geliştirilmiştir.

${ }^{* *}$ Ankara Üniversitesi Eğitim Bilimleri Fakültesi Eğitim Bilimleri Bölümü, orcid.org/ 0000-0002-8004-020X, ozge.erdemli8787@gmail.com.

****Ankara Üniversitesi Eğitim Bilimleri Fakültesi Eğitim Bilimleri Bölümü, orcid.org/0000-0003-2653-2673, tugbaguner87@gmail.com.
}

$\begin{array}{lll}\text { Gönderim: } 10.01 .2018 & \text { Kabul:27.03.2018 } & \text { Yayın:10.09.2018 }\end{array}$




\section{Receiving Gift in terms of Teacher Professional Ethics: An evaluation in the Case Study}

Abstract: The purpose of this study is to identify the approaches, teachers use to justify and rationalize receiving gifts. For this purpose, the opinions of the teachers were asked. In this study qualitative research method and a case study design were used since the opinions of teachers, who tried to justify and rationalize receiving gifts, were deeply examined. The study group is comprised of 15 teachers working in public primary and secondary schools in Ankara. In this study, a case about receiving gifts was given to the teachers and then what they would do in this case and the underlying reasons for these decisions were asked. In addition, it has been tried to determine which approaches are being used to justify and rationalize these decisions. The data were analyzed by using descriptive analysis. According to the research findings, it is seen that most of the teachers make ethical decisions in the case given to them, but it has been indicated that some teachers accept gifts for various reasons. It has been seen that teachers use the approach of "trap of fake necessities" while rationalizing and justifying these unethical decisions.

Keywords: Gift, unethical behavior, teachers, professional ethics, rationalization. 


\section{Giriş}

Günümüzde ailelerin öğretmenler günü gibi özel günlerde öğretmenlere hediye alma konusunda bir yarış içinde olduğu görülmektedir. Özellikle ailelerin hediye almamaları durumunda çocukları ile ilgilenilmeyeceği yönündeki algıları, bu davranışın günden güne daha fazla yaygınlaşmasına neden olmaktadır. Diğer taraftan hediye alma, öğretmenler açısından da bir saygınlık göstergesi olarak görülmektedir. Nitekim öğretmenler gününde az hediyeye sahip olmak küçük düşürücü bir durum gibi algılanmaya başlamıştır. Sosyal medyada öğretmenlerin kendilerine gelen hediyeleri paylaşarak, en fazla ya da en pahalı hediyeyi almayı "iyi öğretmen olmak" ile bağdaştırdığı görülmektedir. Bu durum ise öğretmenlik mesleğinin hediyenin değeri ile ölçülmesine neden olmakta ve mesleğin değersizleşmesine yol açmaktadır. Bu açıdan öğretmenlik mesleği açısından hediye alma konusu tartışılması gereken önemli konulardan biridir.

Her meslekte olduğu gibi öğretmenlik mesleğinde de mesleğin gereklerini yerine getirmek adına çalışanların uymaları gereken kurallar meslek etiğinin ilgi alanına girmektedir. Meslek etiği, örgütlerin kararlarında, davranışlarında ve politikalarında doğru ve yanlışın ne olduğu ile ilgilidir. Başka bir deyişle meslek etiği insanlara ekonomik ilgileri ile sosyal sorumlulukları arasında denge kurmasını sağlamak için çeşitli ilkeler sağlamakta ve bu konuda onlara rehberlik etmektedir (Weiss, 2006). Öğretmenlik mesleğinde de hizmet ideallerine ulaşmak için geliştirilen çeşitli etik ilke ve kodlar bulunmaktadır. Bu ilke ve kodlar kısaca profesyonellik, hizmette sorumluluk, adalet, eşitlik, sağlıklı ve güvenli bir ortamın sağlanması, yolsuzluk yapmamak, dürüstlük, doğruluk, tarafsızlık, mesleki bağlılık ve sürekli gelişme, saygı ve kaynakların etkili bir şekilde kullanılması olarak sıralanmaktadır (Aydın, 2012). Ancak "bir öğretmenin öğrencisinden hediye alması", yukarıda bahsedilen bu etik ilkelerin 
ihlal edilmesine yol açabilmektedir. Dolayısıyla eğitim örgütlerinde öğrenciden hediye alınması önemli bir öğretmenlik meslek etiği konusudur.

Armağan olarak da ifade edilen hediye, Türk Dil Kurumu tarafından "birini sevindirmek, mutlu etmek için verilen şey” olarak tanımlanmıştır (www.tdk.gov.tr). Kamusal anlamda ise hediye çalışanın tarafsızlığını, performansını, kararını ya da görevini yapmasını etkileyen veya etkileme ihtimali olan, maddi değeri olan ya da olmayan, doğrudan veya dolaylı olarak kabul edilen her türlü eşya ve menfaat şeklinde belirtilmektedir (Kamu Görevlileri Etik Kurulu, 2017). Hediyenin doğum ve doğum günleri, düğünler, tebrikler, anneler günü gibi önemli olaylarla ilişkili sembolik bir iletişim aracı olarak görülmesi, bu davranışın yazılı tarihten itibaren tüm kültürlerin ve toplumların bir parçası olmasını sağlamıştır. Dolayısıyla hediye verme evrensel bir davranış olarak kabul görmektedir (Aarthy ve Verma, 2014). Hediyeler insanlar arası ilişkilerin sürdürülmesinde ve güçlendirilmesinde sembolik bir destekleyici olarak rol oynamaktadır (Komter, 1996; Akt. Shanka ve Handley, 2011). Bunların yanı sıra hediye verme toplumsal açıdan devamlılığı ve dayanışmayı sağlamasından dolayı toplumlar için bir gereklilik olarak algılanmakta ve hediye vermenin hediye almak kadar önemli bir yükümlülük olduğu belirtilmektedir (Mauss, 1966; Akt. Demez, 2011). Görüldüğü gibi hediye, sosyal ilişkilerin güçlendirilmesi ve sürdürülmesinde önemli bir işleve sahiptir. Bu açıdan da hediyeleşme davranışını tüm toplumlarda gözlemlemek mümkündür.

Hediyenin sosyal ilişkilerin oluşmasında sembolik bir değeri olduğunu vurgulayan Sherry (1983), hediye verme sürecini üç aşamalı bir modelle açıklamaktadır. Bu aşamalar; fikir aşaması (gestation), hediye verme aşaması (prestation) ve yeniden düzenleme aşamasıdır (reformulation). Fikir aşaması, gerçek hediye alışverişi aşaması öncesindeki tüm davranışları kapsamaktadır. Bu aşama genellikle belirli gün ve haftalarda veya kişinin gönüllü olarak hediye alma isteği ile başlamaktadır. Fikir aşaması boyunca hediye veren kişi, hediye alınacak kişiye 
ve ne hediye verileceğine ilişkin bir değerlendirme yapmaktadır. İkinci aşama olan hediye verme aşaması, hediye paketlemeyi de içeren hediye alış verişinin gerçekleştiği aşamadır. Bu aşama hediyeyi veren ile alan arasında gerçekleşen bir etkileşimdir. Hediye verme ritüelleri ve törenler bu aşamada yer almaktadır. Son aşama olan yeniden düzenlemede ise hediyeyi veren ile alan kişi arasındaki ilişkinin yeniden düzenlenmesi ele alınmaktadır. Buna göre hediyeyi alan kişi bir değerlendirme yaparak hediyeyi veren kişiyle ilişkisini onaylayabilmekte, güçlendirebilmekte, zayıflatabilmekte veya bu ilişkiyi sonlandırabilmektedir. Ayrıca bu değerlendirme sonucuna göre kişi hediyeyi kabul edebilmekte (tüketebilir), sergileyebilmekte, saklayabilmekte, değiştirebilmekte veya reddebilmektedir.

Türk toplumunda bayramlarda, yaş günlerinde, düğünlerde, doğumlarda, sünnetlerde, mezuniyetlerde hediye almak bir gelenektir. Hediye alırken dikkat edilen en önemli husus ise hediyenin yararlı olması, bir işe yaramasıdır (Tunç, 2004). Hediye karşıdaki kişiye değer verildiğini, sevildiğini göstermenin bir sembolü olmakla birlikte hediye veren kişi bir başarıyı kutlamak, güzel bir günü anmak, özür dilemek, yıl dönümlerini hatırlamak gibi çok çeşitli amaçlarla hediye verebilir (Sakarya, 2006). Görüldüğü gibi Türk toplumunda hediyeleşme önemli bir gelenektir. Ancak hediyeleşme toplumdan topluma, kültürden kültüre farklı şekilde algilanabilmektedir. Örneğin Japonlar, Araplar ve Akdenizliler (İtalyanlar, İspanyollar ve Türkler) gibi yüksek bağlamlı kültürler hediye vermeyi bir zorunluluk olarak görme eğilimindedirler. Bu kültürlerde hediye verme alışkanlıkları karmaşık, hassas ve nispeten daha anlamlı etkinlikler olarak kabul edilmektedir. $\mathrm{Bu}$ toplumlarda toplumsal üyeler birbirlerine daha sık ve daha kolay borç ya da ödünç verebilmekte ve ömür boyu ilişki kurma konusunda güçlü bir eğilim göstermektedirler. Öte yandan Amerika Birleşik Devletleri (ABD), Almanya ve İsviçre gibi düşük bağlamlı ülkelerde ise iş ortamında hediye verme isteğe bağl1/zorunlu olmayan bir etkinlik olarak görülmektedir. Bu toplumlarda, yüksek değerli ticari hediyeler 
onaylanmamakta ve genellikle işletme yöneticileri tarafından kabul edilmemektedir. Dahası bu kültürlerde pahalı hediyeler genellikle alıcı tarafından rüşvet olarak algılanabilmektedir (Arunthanes, Tansuhaj ve Lemak, 1994). Özetle kültürler arasında hediye verme davranışına bakış açıları arasında farklılıklar olduğunu söylemek mümkündür.

Kültürler arası farklılıkların yanı sıra ülkelerin zaman içinde yaşadıkları sosyal ve kültürel değişimleri de hediyeleşme konusundaki algılamaları etkileyebilmektedir. Örneğin teknolojik gelişmelerle yaşamda çok daha fazla yer edinen kitle iletişim araçlarının bileşkesi olan internet tüm dünyada olduğu gibi Türkiye'de de hediyeleşme geleneğini farklılaştırmaktadır. Bu farklılaşma sonucunda hediye almanın bir kültür ekonomisi sektörü haline geldiği görülmektedir. Yaşamın her anında hediyeleşmeyi sağlayacak şekilde dönüştürmek isteyen hediye sektörünün profesyonelleri, ulusal ve yöresel geleneklerden yararlanmanın yanı sıra daha önce olmayan anneler günü, babalar günü, sevgililer günü gibi vesileler de yaratmaktadır. Talep yaratmayı amaçlayan bu süreçte oluşturulan bu anlam ve ürünlerin tükettirilmesinde medyada yapılan tanıtımlar büyük rol oynamaktadır. Özellikle internette doğrudan ya da dolaylı olarak hediyelik eşya satmayı amaçlayan altı milyonu aşkın site bulunmaktadır (Özdemir, 2008). Türkiye'de de bu sektörel değişimlerin yansıması olarak özel günlerde (anneler günü, babalar günü, öğretmenler günü, yılbaşı, sevgililer günü gibi) hediye alışverişi konusunda bir artış olduğu gözlemlenmektedir.

Hediye sektörünün etkisiyle doğum günleri ve özel günlerde (anneler günü, babalar günü, sevgililer günü gibi) alınan hediyeler yanında artık iş ortamında da hediyeleşmenin yer aldığı görülmektedir. İş ortamında hediye vermenin nedenlerini inceleyen Arunthanes ve diğerleri (1994), bu nedenleri üç ana tema altında toplamaktadır. Yazarlar tarafindan bu temalardan ilki hediye verilen kişiye duyulan takdiri ifade etmek, ikincisi kurulan yeni ilişkide karşıdaki kişide olumlu bir izlenim yaratmak ve son olarak karşılık bekleme ilkesi çerçevesinde 
hediye verilen kişinin daha önceki bir iyiliğine karşılık vermek ya da verilen bu hediye karşılığında bu kişiden bir iyilik beklemek olarak ifade edilmektedir. Nomura'ya (2009) göre hediye vererek bireyler, hediye verdikleri kişilerin geçmişte yaptıkları cömert bir davranışlarına karşılık vermeyi veya gelecekte bu kişilerden cömert bir davranış görmeyi ummaktadırlar. Başka bir anlatımla hediye verme karşılık bekleme yükümlülügünü doğurabilmektedir. Diğer taraftan Venkatesan (2011) ise hediyenin karşılık beklenmeden verildiğini savunmaktadır. Hediyenin ne önceki bir hediyenin ya da yaşanmış bir şeyin karşılı̆̆ ne de geleceğe yönelik bir yatırım olmaması gerektiğini vurgulamaktadır. Yazar hediyeyi verenin de alanın da zorunlu bir karş1lık verme düşüncesine sahip olmaması gerektiğini belirtmektedir. Görüldüğü gibi literatürde hediyenin hiçbir karşılık beklenmeden verildiğini savunan görüşler olduğu gibi, her hediyenin bir karşılık bekleme beklentisi oluşturacağını savunan görüşler de yer almaktadır. Aslında görüşlerdeki bu farklılıkların yukarıda bahsedilen kültürel farklılıklardan ya da sosyal ve küresel değişimlerden kaynaklanabileceği iddia edilebilir.

Hediyenin ilişki kurma ve geliştirmede bağlayıcı bir unsur olarak aracılık etmesinin yanı sıra taraflar arasında çıkar bağları oluşturması, yönetimlerin hediye konusunda sınırlar getirmesine ve yasaklayıcı düzenlemeler yapmasına yol açmıştır (Aydın, 2016). Çünkü iş ortamında ilişkileri etkilemek veya sonuçları değiştirmek için hediye verme etik kaygıları da beraberinde getirmektedir (Arunthanes ve diğerleri, 1994). Buna göre Türkiye'de kamu görevlileri açısından bu etik kaygıları ortadan kaldırmak için 657 sayılı Devlet Memurları Kanunun 29. maddesinde kamu görevlilerinin hediye istemeleri ve görevleri sırasında olmasa dahi menfaat sağlama amacı ile hediye kabul etmeleri ya da iş sahiplerinden borç para istemeleri ve almaları yasaklanmıştır. Ayrıca Kamu Görevlileri Etik Kurulu, kamu görevlilerine hediye alma konusunda sınırlamalar getirerek alınabilir ve alınamaz hediyeleri 
yayımladığı yönetmelikle açıklamıştır. Yönetmeliğin 15. maddesi "hediye alma ve menfaat sağlama yasağı” başlığı altında kamu görevlilerinin tarafsızlığını, görevini, performansını ya da kararını etkileyebilecek, ekonomik değerine bakılmaksızın her türlü eşya hediye olarak görülmüş ve kamu görevlilerinin hediye almaması temel ilke olarak kabul edilmiştir. Ancak yönetmelikte kitap, dergi, makale gibi hediyeler, herkese açık konferans, sempozyum, panel gibi etkinliklerde dağıtılan hatıra niteliği taşıyan hediyeler, tanıtım amacı çerçevesinde herkese dağıtılan ve sembolik değeri bulunan reklam ve el sanatları ürünleri gibi hediyeler alınabilir hediyeler kapsamında değerlendirilmiştir. Kamu görevlileri tarafından alınamaz hediyeler kapsamında ise görev yapılan kurumla iş, hizmet veya çıkar ilişkisi içinde bulunanlardan alınan karşılama, veda ve kutlama hediyeleri, burs, seyahat, ücretsiz konaklama ve hediye çekleri, hizmetten yararlananların vereceği her türlü eşya, giysi, takı veya gıda türü gibi hediyeler bulunmaktadır. $\mathrm{Bu}$ bilgilerden hareketle öğretmenlerin eğitim hizmetinden yararlanan öğrencilerinden gelen hediyeleri kabul etmemesi gerekmektedir. Bu yönetmeliğin yanı sıra Milli Eğitim Bakanlığı’nın 24/06/2015 tarihli ve 2015/21 sayılı Eğitimciler için Mesleki Etik İlkeler Genelgesinde öğretmenlerin özel günlerde verilen maddi değeri olmayan sembolik hediyeler dışında, mesleki kararlarını ve tarafsızlıklarını etkileme ihtimali bulunan hediyeleri almaları yasaklanmıştır.

Bilindiği gibi çalışanlar tarafından tüm etik ilke ve kodlar bilinse dahi çalışanlar kimi durumlarda bu ilke ve kurallara uymamaktadır. Yukarıda bahsedilen yasal düzenlemelere rağmen öğretmenlerin özel günlerde öğrencilerinden hediye aldıkları gözlemlenmektedir. Çalışanlar ise bu etik dışı davranışlarını haklı göstermek amacıyla çeşitli gerekçeler ortaya koymaktadır. Pieper (1999) "Başka türlü yapamazdım, yardım etmek zorundaydım” ifadesinin bu tür durumlarda kullanılan önemli bir strateji olduğunu ifade etmektedir. Ayrıca yazara göre söz konusu davranışı toplumun birçok bireyi tarafından benimsenmiş ahlak yasaları ya da belli 
bir ahlak normuyla ilişkilendirmek de etik dışı davranışı haklı gösterirken kullanılan yaygın stratejilerdendir. Türk toplumunda da hediyeleşmenin, kültürü oluşturan bir gelenek olarak görülmesinin, hediye alma yasağına uymamanın haklılaştırılmasını kolaylaştırdığı söylenebilir.

Josephson Etik Enstitüsü (2002; Akt. Aydın, 2012) bireylerin etik dışı davranışlarını ussallaştırırken çeşitli yaklaşımları kullandıklarını belirtmektedir. $\mathrm{Bu}$ enstitü tarafından belirtilen yaklaşımlar; (1) eğer gerekli ise etiktir, (2) sahte gereklilikler tuzağı, (3) eğer yasal ve izin verilebilir ise uygundur, (4) bu işin bir parçası, (5) sonuçta herkesin yararı sağlanacak, (6) bunu sadece senin için yapıyorum, (7) sadece ateşe ateşle karşılık veriyorum, (8) kimse zarar görmeyecek, (9) herkes aynı şeyi yapıyor, (10) kişisel olarak benim kazancım yoksa tamam, (11) hak ettiğimi alamıyorum ve (12) hala tarafsız olabilirim şeklinde sıralanmaktadır (Akt. Aydın, 2012). Görüldüğü gibi bireyler etik dışı davranışları başka insanları ya da kültürel öğeleri referans göstererek, daha önceden uğradığı bir zararın ya da iyiliğin karşılığı olarak ifade ederek veya bu durumun ilerideki davranışlarına bir yansıması olmayacağını belirterek ussallaştırmaya çalışmaktadır. Bu açıdan Türkiye'de oldukça yaygın bir davranış olarak gözlemlenen hediye alma davranışının öğretmenler tarafından nasıl ussallaştıııldığının tespit edilmesi önemli olduğu düşünülmektedir. Ancak yerli literatürde bu konuya özgü yapılan bir çalışmaya rastlanmamıştır. Bu çalışma ile literatürdeki bu boşluk doldurulmaya çalışılmıştır. Bu bilgiler 1şığında bu çalışmanın amacı öğretmenlerin hediye alma etik dışı davranışını haklı gösterirken ve ussallaştırırken kullandıkları yaklaşımları tespit etmektir. Bu genel amaç doğrultusunda araştırmada şu sorulara cevap aranmaktadır:

1. Öğretmenlerin hediye alma konusunda karşılaştıkları örnek olayda verdikleri kararlar mesleki etik ilkeler açısından nasıldır? 
2. Öğretmenler öğrencilerden hediye alma/almama davranışını nasıl gerekçelendirmektedirler?

3. Öğretmenler öğrencilerden hediye alma davranışını ussallaştırırken hangi yaklaşımları kullanmaktadırlar?

\section{Yöntem}

\section{Araştırma Deseni}

$\mathrm{Bu}$ araştırma öğretmenlerin hediye alma davranışını haklı gösterirken ve ussallaştırırken kullandıkları yaklaşımları tespit etmeye yönelik nitel bir araştırmadır. Çalışma öğretmenlerin hediye alma davranışını nasıl haklı göstermeye çalıştıklarını incelediğinden nitel araştırma yaklaşımlarından durum çalışması deseni benimsenerek yapılmıştır. Nitel araştırmalarda durum çalışması, bir olayın derinlemesine çalışılmasını ifade etmektedir (Glesne, 2012). Bu araştırma türünün diğer araştırma yöntemlerinden fark1, nasıl ve niçin sorularına odaklanması ve araştırmacı tarafindan kontrol edilemeyen bir olayın ya da olgunun derinlemesine incelenmesine olanak sağlamasıdır (Yıldırım ve Şimşek, 2016). Bu araştırmada da öğretmenlerin hediye alma davranışını niçin kabul veya reddettikleri ve bu davranışlarını nasıl ussallaştırmaya çalıştıkları derinlemesine incelenmeye çalışılmıştır. Ancak bu çalışma araştırma konusunun doğası nedeniyle Akar'ın (2016) belirttiği durum çalışması desenin çoklu veri kaynaklarından veri toplama şartını karşılayamamaktadır. Etik dışı davranışlar çoğunlukla dışarıdan gözlemci kişilerin olmadığı ortamlarda gizlilik içerisinde gerçekleşmekte ve bu nedenle ortaya çıkarılması oldukça güç olmaktadır (Kamu Görevlileri Etik Kurulu, 2017). Bu sebeple gözlem ya da doküman incelemesi gibi yollarla veri toplanamamış, katılımcıların örnek olay ekseninde görüşlerine başvurulmuştur. 


\section{Çalışma Grubu}

Araştırmanın çalışma grubu amaçlı örnekleme yöntemi ile belirlenmiştir. Bu kapsamda çalışma grubunu Ankara ilinde kamu ilkokul ve ortaokullarında görev yapmakta olan 15 öğretmen oluşturmaktadır. Bu öğretmenlerin 12'si kadın üçü erkektir. Öğretmenlerin branşları incelendiğinde ise dördü sınıf öğretmeni, 11'i branş öğretmeni olarak görev yapmaktadır. Öğretmenlerin mesleki kıdemlerinin yıllara göre dağılımlarına bakıldığında 1-5 yıl arası kıdeme sahip iki öğretmen, 5-10 yıl arası kıdeme sahip altı öğretmen ve 10-15 yıl kıdeme sahip bir öğretmen, 15 yıl ve üzeri kıdeme sahip dört öğretmen bulunmaktadır. İki öğretmen ise kıdemini belirtmemiştir.

\section{Verilerin Toplanması}

Araştırma verileri araştırmacılar tarafından geliştirilen örnek olay ve bu örnek olayla ilgili açık uçlu sorulardan oluşan bir soru formu ile toplanmıştır. Soru formu iki bölümden oluşmaktadır. Birinci bölümde öğretmenlerin kişisel bilgileri yer almakta, ikinci bölümde ise hediye alma durumunu yansıtan bir örnek olay ve bu örnek olaylarla ilgili üç adet açık uçlu soru bulunmaktadır.

Oluşturulan soru formu taslağı kapsam geçerliliği için yedi alan uzmanının görüşüne sunulmuştur. Uzmanlardan örnek olayın ve soruların anlaşılır olma, ele alınan konuyu ve alt amaçları kapsama gibi yönlerden değerlendirmeleri istenmiştir. Uzmanlardan gelen görüşler değerlendirilerek gerekli düzeltmeler yapıldıktan sonra soru formundaki örnek olayın ve soruların anlaşılırlığı için iki öğretmen ile pilot uygulama yapılmıştır. Bu pilot uygulamadan elde edilen geri bildirimler 1şı ğında soru formuna son hali verilmiştir. Oluşturulan form çalışmaya gönüllü olarak katılmayı kabul eden öğretmenlere dağıtılmış ve formu yanıtlamaları için süre verilmiştir. Bu süre sonrasında form araştırmacılar tarafından öğretmenlerden toplanmıştır. 


\section{Geçerlik ve Güvenirlik}

Araştırmada kullanılan soru formunun kapsam geçerliği için yedi alan uzmanının görüşüne başvurulmuştur. Ayrıca iki öğretmen ile pilot uygulama yapılmıştır. Nitel araştırmalarda çalışma grubunun seçiminde kasıtlı olarak çeşitlilik ve farklılık yaratmanın geçerlik ve güvenirlik için kullandığı görülmektedir (Merriam, 2013). Bu sebeple araştırmada hem ilkokul hem de ortaokul öğretmenlerine ulaşılmıştır. Bunun yanı sıra cinsiyet, branş ve mesleki kıdem açısından çeşitlilik yaratılmaya çalışılmıştır. Nitel araştırmalarda güvenirliğin sağlanmasında kullanılan bir başka strateji de aynı araştırmaya birden fazla araştırmacının dâhil edilmesidir. Böylece araştırma sürecinde verilerin toplanması, analizi ve sonuçlandırılması aşamalarında araştırmacılar arasında sağlanan uzlaşma noktaları, sonuçların başkaları tarafından da kabul edilmesini arttıracaktır (Yıldırım ve Şimşek, 2016). Bu araştırmada da verilerin analizde iki araştırmacı birbirinden bağımsız olarak analizleri yapmış ve farklılıklar tartışılarak uzlaşma sağlanmıştır.

Nitel araştırmada inandırıcılığı sağlamak için Creswell (2012) zengin ve ayrıntılı betimleme yapılmasını önermektedir. Bu nedenle verilerin nasıl ve kimden toplandığı, nasıl kaydedildiği ve verilerin nasıl analiz edilip birleştirildiği gibi bilgiler ayrıntılı bir biçimde açıklanmaya çalışılmıştır. Verilerin güvenirliği için ayrıca bulgular sunulurken doğrudan alıntılara yer verilmiştir. Nitekim Yıldırım ve Şimşek’in (2016) belirttiği gibi okuyuculara verileri doğrudan okuma fırsatı verilirse, okuyucuların araştırmacının elde ettiği sonuçları bu alıntılara göre değerlendirme imkânı da olacaktır.

\section{Verilerin Analizi}

Araştırmada veriler nitel araştırma veri analiz tekniklerinden "betimsel analiz tekniği” kullanılarak analiz edilmiş ve yorumlanmıştır. Bu kapsamda öncelikle soru formlarından elde edilen veriler bilgisayar ortamına aynen aktarılarak ham veriler düzenlenmiştir. Daha sonra bu 
veriler alt amaçlara göre araştırmacılar tarafından birbirinden bağımsız olarak analiz edilmiştir. Verilerin analizinde ilgili literatür de göz önünde bulundurularak Josephson Etik Enstitüsü’nün (2002; Akt. Aydın, 2012) belirlemiş olduğu, bireylerin etik dışı davranışlarını ussallaştırırken kullandıkları yaklaşımlar dikkate alınmıştır. Son olarak araştırmacılar analizlerini bir araya getirip ortak ve farklı yönlerini tartışarak sonuçları betimsel bir anlatımla yorumlamıştır. Öğretmenlerden doğrudan alıntı yapılan görüşler, italik biçimde verilerek katılımcının kodu Ö1, Ö2, Ö3 (1'den 15'ye kadar) şeklinde sunulmuştur.

\section{Bulgular}

Çalışmanın bu kısmında öncelikli olarak öğretmenlere sunulan örnek olay verilmiş, daha sonra sorulara verilen cevaplar analiz edilerek sunulmuştur. Öğretmenlerin örnek olaylara verdiği cevaplar öğretmenlik meslek etiği kapsamında değerlendirilmiş ve etik dışı davranışları ussallaştırma yaklaşımları Josephson Etik Enstitüsü'nün belirlemiş olduğu yaklaşımlar çerçevesinde incelenmiştir.

B okulunda öğretmenler gününden bir hafta önce okul müdürü öğretmenlerle bir toplantı düzenler. $\mathrm{Bu}$ toplantıda okul müdürü İl Milli Eğitim Müdürlügünden öğretmenler gününde çiçek dışında hiçbir hediye kabul edilmemesi gerektiğine dair bir yazı geldiğini iletir. Öğretmenler gününde Sevim Öğretmen'e bir öğrencisi hediye olarak altın bir kolye getirir. Ancak Sevim Öğretmen bu hediyeyi kabul etmez. Teneffüste Sevim Öğretmen öğretmenler odasına gittiğinde, diğer öğretmenlerin gelen hediyeleri kabul ettiklerini ve bu öğretmenlerin hediyeyi geri çevirmenin Türk geleneklerinde kabalık ve saygısızlık olacağını gerekçe olarak sunduklarını görür. Bir sonraki ders saatinde Sevim Öğretmen sınıfa gittiğinde hediyesini geri çevirdiği öğrencinin çok üzgün olduğunu görür. Öğrencinin yanına gittiğinde de, öğrenci Sevim Öğretmene hediyesini kabul etmesi için tekrar israr eder.

Öğretmenlere yukarıdaki örnek olay sunulduktan sonra öncelikle, böyle bir durumda nasıl karar verecekleri irdelenmeye çalışılmış ve "bu durumda olsaydınız siz ne yapardınız?" sorusu yöneltilmiştir. Öğretmenlerin 12'si etik dışı davranmayı reddedip hediyeyi almayı kabul etmeyeceklerini belirtmiştir. Ancak öğretmenlerden üçü hediyeyi almayı kabul edeceklerini ifade etmişlerdir. Buna göre öğretmenlerin büyük bir çoğunluğunun mesleki etik ilkelere uygun 
bir şekilde davranmayı seçtikleri ve öğrencilerden gelen pahalı bir hediyeyi almayı tercih etmedikleri görülmektedir. Buna rağmen, öğretmenlerden bazılarının bu pahalı hediyeyi kabul edeceğini belirtmesi sistemde mesleki etik ilkelere aykırı hareket edebilecek öğretmenlerin de bulunduğunu göstermektedir.

Öğretmenlere bu kararlarının gerekçeleri de sorulmuştur. Hediye almayı reddeden öğretmenlerin büyük bir çoğunluğu hediye almanın öğrenci ve velide bir beklenti oluşturabileceğine dikkat çekmiştir. Bu konudaki öğretmen görüşlerinden ikisine aşağıda yer verilmiştir.

Ö8: Çünkü o hediye, öğretmenin sırtında her zaman bir yük olacaktır. Öğrenciyi beklenti içine sokacaktır.

Ö3: Maddi değeri yüksek hediyeleri kabul etmek veliyi ögrenciye ayrıcalıklı davranmak konusunda bir beklenti içine sokabilir.

Öğretmen ifadelerinden görüldüğü gibi hem öğrencilerin hem de velilerin bu hediyeye karş1lık bir beklenti içinde olabilecekleri düşüncesi öğretmenlerin bu kararı vermelerinde etkili olmuştur. Diğer bir ifadeyle öğretmenler daha sonrasında bir çıkar ilişkisi durumundan kendilerini korumak adına böyle bir karar vermişlerdir. Bunun yanında öğrencilerden maddi bir hediye kabul etmenin öğrenci-öğretmen ilişkisine zarar vereceği de belirtilmiştir. Bazı öğretmenler ise, inandıkları değerlerden taviz vermemek ve davranışlarında tutarlı olmak adına böyle bir hediyeyi kabul edemeyeceklerini bildirmişlerdir. Bir öğretmen ise hediye çok pahalı olduğu kabul edemeyeceğini belirtmiştir.

Hediyeyi almayı kabul eden iki öğretmen kararlarına gerekçe olarak, eğer hediyeyi kabul etmezlerse hediye verenin çok üzüleceğini, aldıkları zaman öğrencinin bundan memnun olacağını ifade etmişlerdir. Bu konuda bir öğretmen kararını şu şekilde belirtmiştir: “Burada empati yaparak düşündüğümde, o öğrencinin kırllacă̆ını, üzüleceğini düşünerek kabul 
ederdim.” (Ö16). Bir öğretmen ise bu kararını hediye almanın ve vermenin kültürel bir değer olduğu şeklinde gerekçelendirmiştir. Bu konuda öğretmenin görüşü şu şekildedir.

Ö2: Hediye almak ve vermek kültürel bir değerdir. Burada hediyenin miktarına bakılmaz. Altın kolye veya bir peçete, her ikisi de gönülden gelen saf bir istekle alınmıştır. Zorlama yoktur. Kabul etmemek ileride çocuğun hediye verme konusunda güvensiz ve çekingen olmasina neden olur.

Görüldüğü gibi öğretmen Türk toplumunda hediyeleşme geleneğine dikkat çekmiş ve bu hediyeyi kabul etmediği takdirde öğrencinin de bu değeri yerine getirme konusunda ileride çekingenlik yaşayabileceğini gerekçe olarak göstermiştir. Öğretmenlere son olarak "Bu kararınıza birini ikna etmeniz gerekirse, nasıl bir yol izlerseniz?” sorusu yöneltildiğinde, öğretmenlerin aşağıdaki yolları kullanacaklarını ifade ettikleri görülmektedir.

Ö2: Hediyenin fiyatı olmaz. Hediye gönülden gelen bir sevgidir bazen öpücük, bazen gülümseme, bazen de parayla alınan bir şey. Bizler çocuklarımıza hediyenin parayla ölçülemeyeceğini anlatmalıyı.

Ö4: Öğrenciyi kırmak istemedim, çok üzülür diye düşündüm, diğer arkadaşları arasında mahcup olmaması için aldığımı belirterek ikna etmeye çalışırdım.

Ö16: Hediyenin parasal anlamda büyüklüğ̈̈nün önemi olmadiğını, öğrencinin değerli olduğu duygusunu hissettirmeye çalışırdım.

Öğretmenlerin sundukları yollara bakıldığında, hediyenin parayla ölçülemeyeceğine, maddi olarak pahalı bir hediye olsa da diğer hediyelerden ayrı tutulamayacağına dikkat çektikleri görülmektedir. Ayrıca öğretmenlerin hediye kabul etmemenin öğrencilerde zarara yol açacağını iddia ettikleri görülmektedir. Hediye kabul etmemenin öğrenciler arasında mahcubiyete sebep olacağı, onları duygusal olarak üzeceği ve öğrencinin kendini değersiz hissetmesine yol açacağı gibi gerekçeler öğretmenler tarafından ifade edilmiştir. Bu ifadeler incelendiğinde öğretmenlerin bu etik dışı kararlarını haklı gösterirken ve ussallaştırırken “Sahte gereklilikler tuză̆g” ussallaştırma yaklaşımını kullandıkları görülmektedir. Yani öğretmenler kendilerine göre bazı gereklilikler oluşturmuşlar ve bunları etik dışı davranışın uygun sayılması için yeterli olacağı gibi bir varsayıma dayandırmışlardır. 


\section{Tartışma, Sonuç ve Öneriler}

Araştırmaya katılan öğretmenlerin görüşleri incelendiğinde çoğunun kendilerine verilen örnek olayda etik karar verdikleri ve öğrenci tarafından sunulan pahalı hediyeyi kabul etmedikleri görülmektedir. Uzun ve Elma (2012) tarafından yapılan araştırmada da okul öncesi öğretmenlerle görüşmeler yapılmış ve öğretmenlerin büyük bir kısmı velilerden gelen değerli hediyeyi kabul etmeyeceklerini belirtmiş ve bunu etik dışı bir davranış olarak değerlendirmişlerdir. Bu araştırmada öğretmenler böyle bir karara ulaşmalarında bu durumun ileride bir beklentiye yol açabileceği, başka bir anlatımla çıkar ilişkisi yaratma olasılığı bulundurmasının etkisi olduğunu vurguladıkları görülmektedir. Nitekim Nomura (2009) da bireylerin hediye vererek gelecekte bu kişilerden cömert bir davranış görmeyi umduklarını belirtmektedir. Mauss (1925) da benzer şekilde hediye kavramında karşılıklılık ilkesini kullanmakta ve yaptığı çalışmasında her hediye ile ilgili bir dönüş beklentisinin (bilinçli veya bilinçsiz) bulunduğunu vurgulamaktadır (Akt. Shanka ve Handley, 2011). Gouldner ise hediye verme davranışının karşılık verme yükümlülüğünü getirebildiğini belirtmekte, ancak yazar hediyeye karş1lık verme yükümlüğünü özgeci bir hediye almaktan ayırmaktadır. Buna göre karşılığında hiçbir şey beklenmeyen özgeci hediyeler olan saf hediyeler hariç tutulursa, çoğu durumda hediye veren kişiler hediyeyi alan kişilerden bir yarar sağlamayı beklemektedirler. $\mathrm{Bu}$ yarar hediye alan kişiden bir kazanç elde etme, bir ilişkinin sürdürülmesi ve/veya geliştirilmesi ya da hediyeyi veren kişinin üstünlüğünü kabul etme şeklinde olabilmektedir (Akt. Nomura, 2009). Dolayısıyla hediye karşılığında beklenen yararın sadece maddi olmadığını söylemek mümkündür. Bu sebeple öğretmenlerin gelen her hediyenin maddi olmasa da bir beklentiye yol açabileceğini unutmamaları gerekmektedir.

Öğretmenlerden bazıları hediyeyi kabul etmelerine gerekçe olarak Türk kültüründe hediyeleşmenin önemli bir değer olduğunu ve hediyeyi kabul etmemenin bu değerlerin yok 
olmasına neden olabileceğini göstermiştir. Türk kültüründe hediyeleşme önemli bir gelenektir, ancak bu kültürde de hediyelerde genellikle karşılıklılık ilkesinin gözetildiği söylenebilir. Çünkü Tomak ve Güney'in (2014) de ifade ettiği gibi Türkler hediye getiren kişiye hediye götürürken hediyesine denk bir şey götürmeye özen göstermektedir. Dahası bunun sağlanabilmesi için yazarların belirttiği üzere bazı kırsal bölgelerde düğünlerde gelin ve damada verilen hediyeler sesli olarak duyurulmaktadır. Buna göre Türk kültüründe gelen hediyeye denk bir hediye götürülmesinin bir zorunluluk gibi algılanabileceği söylenebilir. Dolayısıyla kültürün bu yönü de unutulmadan iş ortamında gelen hediyelerin çoğunlukla bir beklenti karşılığında verileceğini unutmamakta yarar vardır. Çünkü iş ortamında verilen hediyeler genellikle bireyin kendisine değil içinde bulunduğu mevkiye, statüye verilmektedir. Bu nedenle de karşılığında bir beklenti oluşturması muhtemeldir.

Araştırmanın sonuçlarına göre bazı öğretmenlerin ise çeşitli gerekçelerle hediye alma yasağını ihlal etmeyi tercih ettikleri görülmektedir. Öğretmenlerin bu etik dışı kararlarını ve davranışlarını haklı gösterirken ve ussallaştırırken ise "Sahte gereklilikler tuzağı” yaklaşımını kullandıkları tespit edilmiştir. Öğretmenlerin yarattıkları sahte gerekliliklerden ilki hediyenin alınmaması durumunda öğrencinin üzülmesi, yani duygusal olarak zarar görmesidir. Ancak öğrencinin üzülmemesi için öğretmenin hediye kabul etmesinin öğrenciler açısından daha büyük sorunlara yol açabileceğini söylemek mümkündür. Örneğin Aydın (2016) üniversitelerde akademisyenlerin öğrencilerinden hediye almasının, akademisyenlerin tarafsızlığını bozacağını, akademisyenin değerlendirme, iletişim ve benzeri konulardaki tarafsızlığını ve kararını etkileyeceğini ve bunun diğer öğrenciler aleyhine bir durum yaratabileceğini vurgulamaktadır. Ayrıca yazar eğiticilerin öğrenciler için bir rol model olmasına vurgu yaparak, öğrencilerden hediye kabul edilmesinin, öğrencilerin bu konudaki 
eğilimlerini teşvik edeceğini ve diğer öğrencilerin de bu davranışı örnek alacağını belirtmektedir.

Buraya kadar tartışılanlar 1şığında bir eğitimci olarak öğretmenlerin öğrencilerinden hediye kabul etmesinin, eğitim öğretim etiğinin temel ilkelerinden biri olan tarafsızlık ilkesine zarar vereceğini söylemek mümkündür. Dolayısıyla hediye almanın öğretmenin öğrencilerle ilgili tüm karar ve davranışlarını etkileyebileceğini, öğretmenlerin bu hediyeye bağlı olarak öğrencilere yanlı bir şekilde davranabileceğini, öğretmen yanlılık içeren davranışlar sergilemese dahi diğer öğrencilerde böyle bir algı oluşabileceğini söylemek mümkündür. Buna ek olarak öğretmene pahalı hediyelerin verilmesi, maddi açıdan hediye alamayacak durumda olan öğrencilerin veya maddi değeri olmayan ya da maddi değeri az hediye alan öğrencilerin de kendilerini kötü hissetmelerine neden olabilir. Bu duruma paralel olarak hediyelerin maddi yönlerinin ön plana çıkarılması velilerin de bir rekabet içinde girmesine yol açabilmektedir. Bütün bunların yanı sıra hediye verme davranışı daha önce de bahsedildiği gibi hediye veren kişilerde bir beklenti yaratabilmektedir. Öğrencilerin ve velilerin verdikleri hediyenin büyüklügüüne göre bir beklenti içine girmesi kaçınılmaz olacaktır. Son olarak öğretmenin hediye kabul etmesi, bu davranışın yaygınlaşmasına da zemin hazırlayacaktır. Buna göre öğrencilik döneminde öğretmenlerine hediye vererek bir beklenti içine giren öğrenciler, ileride bir meslek sahibi olduklarında hizmet sundukları kişilerden hediye beklentisi içine girebileceklerdir. Dolayısıyla bir öğretmenin öğrencisinden hediye kabul etmesinin eğitim öğretim sürecini olumsuz bir şekilde etkilediğini ve öğrenci açısından olumsuz sonuçlara yol açtığııı söylemek mümkündür.

Öğretmenin hediye alması sadece öğrenciye değil öğretmene de zarar verebilmektedir. Örneğin; Almanya'da yaşanan bir olayda, bir lisede mezun olacak öğrenciler öğretmenlerine kendi aralarında para toplayarak 200 Euro değerinde bir veda hediyesi almış, öğretmenleri de 
bu hediyeyi kabul etmiştir. Öğrencilerin velilerinden birinin bu durumu öğrenip şikâyet etmesiyle başlayan rüşvet davasında öğretmen 4000 Euro para cezası ödemeyi kabul etmiştir. Berlin Eğitim Senatörlüğü yolsuzluk ve rüşvetin önüne geçmek amaciyla şehirdeki sadece öğretmenlerin değil tüm kamu görevlilerinin 10 Euro'dan fazla değere sahip tüm hediyeleri kabul etmesini yasaklamıştır (Hürriyet, 2015). Görüldüğü gibi bu olayda öğretmen hem aldığı parasal ceza karşılığında maddi zarara uğramış hem de yaşadığı bu süreç belki de duygusal olarak yıpranmasına, dahası toplum tarafından kendine duyulan saygınlığın azalmasına yol açmış olabilir. Yaşanan bu olayda öğrenciler ile öğretmenin bir daha bir araya gelme ihtimalinin bulunmadığı ve dolayısıyla bu durumun rüşvet gibi algılanmasının doğru olmadığı düşünülse de, böyle bir olay toplumda yolsuzluk algısının artmasına neden olacak ve kamu görevlisine duyulan güveni sarsacaktır. Öğretmenlerin özellikle değerli hediyeleri kabul etmesi de onlara duyulan güvenin azalmasına ve öğretmen saygınlığının ve statüsünün düşmesine neden olabilecektir. Bu nedenle öğretmenlerin hediye alması hem öğrenci ve öğretmen hem de öğretmenlik mesleği açısından zarar verici olabilmektedir.

Öğretmenlerin ifade ettiği diğer bir sahte gereklilik, hediyenin parayla ölçülemeyeceği yönündeki algılarıdır. Aslında bu algılarında Türkiye'nin kültürel olarak yüksek bağlamlı bir ülke olmasının etkisi olabilir. Çünkü Arunthanes ve diğerlerinin (1994) belirttiği gibi yüksek bağlamlı bir kültürde (Japonlar, Araplar ve Akdenizliler [İtalyanlar, İspanyollar ve Türkler]), kişinin sahip olduğu pozisyon veya statü, çeşitli insanlar için hediye değerinin belirlenmesinde çok kritiktir. Diğer bir deyişle, hiyerarşi gücüne göre hediye değerlerinin de bir hiyerarşisi vardır. Düşük bağlamlı bir kültürde ise pahalı hediyeler rüşvet olarak yanlış algılanabilmektedir. Başka bir anlatımla yazarlar bir hediyenin kabul edilebilir fiyat aralığının, kültürel ve hukuki faktörlere bağlı olarak değişiklik gösterebildiğini vurgulamaktadır. Dolayısıyla yüksek bağlamlı bir kültüre sahip Türkiye'de yüksek statüye sahip mesleklerde 
değerli bir hediye kabul etmenin etik dışı bir davranış olarak algılanmayacağını söylemek mümkündür. Öğretmenler de bu davranışlarını bu algılarına göre açıklamış olabilir. Ancak yüksek statülü bir meslekte çalışmanın değerli hediyeleri kabul etme hakkını getirdiğini düşünmenin ne kadar etik olduğu tartışmalıdır. Ayrıca bu mesleklerde de hediyenin bir çıkar ilişkisine ya da karşı taraftan bir beklenti hissine yol açabileceği, çalışan ve hizmetten yararlananlar açısından bir zarara neden olabileceği unutulmamalıdır.

Araştırmada dikkat çeken önemli bir bulgu öğretmenlerin büyük çoğunluğunun hediye almayı kabul etmeyeceğini bildirmesidir. Ancak bu sonucun, sosyal beğenirliğin bir sonucu olması da muhtemeldir. Bir kamu görevlisi olan öğretmen, mevcut yasal düzenlemeler nedeniyle hediyeyi kabul etmemesi gerektiğini bilmektedir. Dolayısıyla ister istemez buna uygun yanıt vermiş olabilmektedir. Mevcut uygulamalara bakıldığında ise özellikle öğretmenler günü, yılbaşı gibi özel günlerde öğretmenlerin genel olarak hediyeleri bu kadar net bir şekilde geri çevirmediği gözlemlenmektedir. Diğer taraftan araştırmanın nitel araştırma yöntemi benimsenerek yapıldığg ve 15 öğretmenin görüşleriyle sınırlı olduğu göz önüne alınırsa, bu sonuçları tüm öğretmenlere genellemenin mümkün olmayacağı söylenebilmektedir. Dolayısıyla öğretmenlerin hediye alma davranışlarını inceleyen daha kapsamlı çalışmalara ihtiyaç olduğu açıktır. Ayrıca gelecekteki çalışmalarda öğrenciler ve veliler gözünden de bu davranışın incelenmesi literatüre katkı sağlayacaktır.

Öğretmenlerin etik dışı davranışları haklı gösterme ve ussallaştırma çabalarının en aza indirilmesinin etik dışı davranışları azaltmada oldukça önemli olduğu düşünülmektedir. Çünkü etik dışı davranışları bu şekilde ussallaştırmayı alışkanlık haline getiren kişi kendini etik dışı davranmanın cazibesine kapılmaktan alıkoyamayacaktır. Bu sebeple öğretmenlerin etik dış1 davranışları haklı gösterme ve ussallaştırmada kullandıkları bu yöntemleri en aza indirmenin faydalı olacağı düşünülmektedir. Bu nedenle de öğretmenlere bu konuda farkındalık yaratacak 
etkinlikler düzenlemek yerinde olacaktır. Çünkü öğretmen hediye alma davranışının sadece rüşvet yerine geçtiği için yasaklandığını düşünmekte, bu davranışın eğitim öğretim sürecinde yarattığı sorunların farkında olamayabilmektedir. Dolayısıyla öğretmenlere hediye alma yasağının eğitim öğretim açısından zararları konusunda seminerler düzenlemesi faydalı olacaktır. Ayrıca eğitim fakültelerinde eğitim öğretim sürecindeki bu etik sorunların tartışılması geleceğin öğretmenlerinin bu konularda daha bilinçli olmasını sağlayacaktır.

\section{Makalenin Bilimdeki Konumu (Yeri)}

Eğitim Bilimleri, Eğitim Yönetimi Anabilim Dalı

\section{Makalenin Bilimdeki Özgünlüğü}

Bir eğitimci olarak öğretmenlerin öğrencilerinden hediye kabul etmesinin, eğitim öğretim etiğinin temel ilkelerinden biri olan tarafsızlık ilkesine zarar vereceğini söylemek mümkündür. Türkiye'de oldukça yaygın bir davranış olarak gözlemlenen hediye alma davranışının öğretmenler tarafından nasıl ussallaştırıldığının tespit edilmesinin bu açıdan önemli olduğu düşünülmektedir. Ancak yerli literatürde bu konuya özgü yapılan bir çalışmaya rastlanmamıştır. Dolayısıyla söz konusu bu çalışmanın özgün bir değer taşıdı̆̆ı düşünülmektedir. 


\section{Kaynakça}

Aarthy, C.J. ve Verma, S. (2014). Factors affecting gifting behavior: Comparitive study of males and females. https://www.researchgate.net/publication/266477912_Factors_Affecting_Gifting_Beh avior_Comparative_Study_of_Males_and_Females adresinden alınmıştır. Erişim Tarihi: 19.12.2017

Akar, H. (2016). Durum çalışması. A. Saban, A. Ersoy. (Ed.), Eğitimde nitel araştırma desenleri içinde (ss. 111-150). Ankara: Anı Yayıncıl1k

Arunthanes, W., Tansuhaj, P. ve Lemak, D. J. (1994). Cross-cultural business gift giving a new conceptualization and theoretical framework. International Marketing Review, 11(4), 44-55.

Aydın, İ. (2012). Ĕgitim ve ögretimde etik. Ankara: Pegem-A Yayıncılık.

Aydın, İ. (2016). Akademik etik. Ankara: Pegem-A Yayıncılık.

Creswell, J. (2012). Educational research: Planning, conducting, and evaluating quantitative and qualtative research. (Fourth Edition). New Jersey: Pearson Education, Inc.

Demez, G. (2011). Armağanın değișen sosyo-kültürel anlamları: Tüketim toplumu bağlamında bir hediyeleşme örneği olarak çiçek gönderme. Mediterranean Journal of Humanities, $1(2), 87-103$.

Devlet Memurları Kanunu. (1965). Resmi Gazete, 12056,13 Nisan 1965.

Eğitimciler İçin Mesleki Etik İlkeler Genelgesi. (2015). 2015/21, 24 Haziran 2015. https://ikgm.meb.gov.tr/genelge_gorus_yonerge/ET\%C4\%B0K\%20GENELGE.pdf adresinden alınmıştır. Erişim Tarihi: 21.12.2017 
Glesne, C. (2012). Nitel araştırmaya giriş. (Çev.: A. Ersoy ve P. Yalçınoğlu). Ankara: Anı Yayınc1lı.

Hürriyet. (2015). Hediye kabul eden öğretmene ceza. http://www.hurriyet.com.tr/hediyekabul-eden-ogretmene-ceza-27881295 adresinden alınmıştır. Erişim Tarihi: 21.12.2017.

Kamu Görevlileri Etik Davranış İlkeleri İle Başvuru Usul ve Esasları Hakkında Yönetmelik. (2005). Resmi Gazete, 25785, 13 Nisan 2005.

Kamu Görevlileri Etik Kurulu. (2017). Kamu görevlileri etik rehberi. http://etik.gov.tr/Portals/0/anasayfa/etik_rehberi.pdf adresinden alınmıştır. Erişim Tarihi: 24.03.2018.

Merriam, S. B. (2013). Nitel araştırma desen ve uygulama için bir rehber. (Çev. Ed.: S. Turan). Ankara: Nobel Yayıncılık.

Nomura, M. (2009). Gift Giving Anxieties as a Function of Recipient Characteristic. (A Research Paper for the Master of Science Degree). University of Wisconsin-Stout.

Özdemir, N. (2008). Türk hediyeleşme geleneği ve medya. Journal of International Social Research, 1(4).

Piepper, A. (1999). Etiğe giriş, (Çev.: V. Atayman ve G. Sezer). İstanbul: Ayrıntı Yayınları.

Sakarya, C. I. (2006). Türk kültüründe hediyeleşme geleneği ve hediyeler. (Yayımlanmamış yüksek lisans tezi). Hacettepe Üniversitesi Sosyal Bilimleri Enstitüsü, Ankara.

Shanka, T. ve Handley, B. (2011). Gift giving: An exploratory behavioural study. Asia Pacific Journal of Tourism Research, 16(4), 359-377.

Sherry, J. F. (1983). Gift giving in anthropological perspective. The Journal of Consumer Research, 10(2), 157-168. 
Tomak, A. ve Güney, E. (2014). Kültürel bir değer olarak hediye geleneği ve ekslibris. International Journal of Ex-libris, 1(2), 25-33.

Tunç, A. (2004). Bir maniniz yoksa annemler size gelecek: 70'li yıllarda hayatımız. İstanbul: Yap1 Kredi Yayınları.

Uzun, E. M. ve Elma, C. (2012). Okul öncesi öğretmenlerinin mesleki etik ikilemleri çözümleme biçimleri. Eğitim ve Öğretim Araştırmaları Dergisi, 1(3), 279-287.

Venkatesan, S. (2011). The social life of a "free" gift. American Ethnologist, 38(1), 47-57.

Weiss, J. W. (2006). Business ethics: A stakeholder and issues management approach. Thomson South-Western, Kanada.

Yıldırım, A. ve Şimşek, H. (2016). Sosyal bilimlerde nitel araştırma yöntemleri. Ankara: Seçkin Yayıncılı. 


\section{Summary}

Problem Statement. Nowadays, families are eager and even in a competition to purchase gifts for teachers. Especially, on Teacher's day, families are in a competition with eacher other to buy the most precious gift for the teachers. In this case, it has been pointed out that families try to quantify the importance of teaching profession with a gift and make the social status of teaching profession decrease.

Some behavioral differences can be seen about giving gifts among cultures. For instance, in Turkish society, it is a tradition to purchase gifts on birthdays, weddings, graduation of students (Tunç, 2004). Furthermore, there is a significant increase in buying gifts according to changing cultural and social habits (Valentine day, Christmas, Mother's day etc.).

There are various ethical principles and codes which aim to achieve the ideals of teaching (Responsibility, Honesty, Respect and Effective usage of resources etc.) (Aydin, 2012). Yet, "accepting gifts from students" can lead to a violation to these ethical principles which are mentioned above. Moreover, teachers are eager to put forward various reasons to justify these unethical behaviors. Ethical Institute of Josephson has introduced some approaches on rationalization of unethical behaviors of individuals: (1) It is ethical if it is "necessary", (2) Trap of "fake necessities", (3) It is appropriate, if it is legal and "can be allowed", (4) It is appropriate, if nobody is harmed, (5) "I can still behave objectively." (Akt. Aydin, 2012).

Purpose of the Study: The purpose of this study is to identify the approaches that teachers use to justify and rationalize receiving gifts and in line with this purpose, the following questions were answered:

1. How is the reaction of teachers according to professional ethical principles in terms of accepting gift in the sample case?

2. How do the teachers justify their behavior of accepting/rejecting gifts? 
3. Which approaches are used by the teachers while rationalizing their behaviour of accepting gift from students?

Method(s): In this study, a case about receiving gifts was given to the teachers and then what they would do in this case and the underlying reasons for these decisions were asked. In addition, it has been tried to determine which approaches are being used to justify and rationalize these decisions. A case study in qualitative research refers to an in-depth study of an event (Glesne, 2012). The study group was determined by using a criterion sampling method and was comprised of 15 teachers working at public primary and secondary schools in Ankara. In the study group, 12 participants are female, while 3 participants are male. The research data were collected by means of a questionnaire, which includes the sample case and open-ended questions about this case, and is developed by the researchers. The questionnaire form consists of two parts. In the first part, the personal information of teachers is asked. In the second part, there is a case study reflecting the incident of receiving gifts and including three open-ended questions. The collected data were analyzed by using descriptive analysis.

Findings and Discussions: After the sample case was introduced to the teachers, firstly, "how they would decide in such a situation" was examined and the question of "if you were in a situation like this, what would be your reaction" were asked to them. Twelve teachers responded that they would reject the gift in such a situation. Yet, three of them stated that "they would gladly accept the gift" in such a situation. In addition to this, the underlying reasons for their decisions also were asked to the teachers. The teachers who rejected gifts from the students stated that if they had accepted such gifts, this could have created expectations for both students and their parents. Thus Nomura (2009) also have stated that individuals have expectations when people accept their gifts. Two of the teachers, who accept gifts from their students, stated that if they had rejected such a gift, both students and their parents would have 
been upset and when they accepted them they would be glad. One teacher who accepted the gift from the students justified his decision by saying that accepting gift from other people was a cultural value.

While examining the underlying reasons, told by the teachers, they frequently have stated that, gifts should not be seen only with their value and also they claimed that, rejecting gifts from students can harm students emotionally. When these statements are examined, it is clear that the teachers who accept gifts from students use "trap of fake necessities" approach while justifying their unethical decision.

Conclusions and Recommendations: When the opinions of the teachers who participated in the research are examined, it is seen that most of them make ethical decisions in the case given to them and do not accept the gift. On the other hand, a teacher accepting gifts from his/her students will harm the principle of impartiality, which is one of the basic principles of teaching and learning. It would be useful to arrange seminars on the harms of giving gifts to teachers for educational purposes. In addition, the discussion of these ethical issues in the faculty of education ensures that teachers will be getting more conscious about these issues. Besides these, legal regulations in this issue can be strengthened.

Keywords: Gifts, unethical behavior, teachers, professional ethics, rationalization. 